\title{
Laccase Production from a Temperature and pH Tolerant Fungal Strain of Trametes hirsuta (MTCC 11397)
}

\author{
Kusum Dhakar and Anita Pandey \\ G. B. Pant Institute of Himalayan Environment and Development, Kosi-Katarmal, Almora, Uttarakhand 263 643, India \\ Correspondence should be addressed to Anita Pandey; anita@gbpihed.nic.in
}

Received 7 February 2013; Revised 19 March 2013; Accepted 19 March 2013

Academic Editor: Jose Miguel Palomo

Copyright (C) 2013 K. Dhakar and A. Pandey. This is an open access article distributed under the Creative Commons Attribution License, which permits unrestricted use, distribution, and reproduction in any medium, provided the original work is properly cited.

Laccase production by a temperature and $\mathrm{pH}$ tolerant fungal strain (GBPI-CDF-03) isolated from a glacial site in Indian Himalayan Region (IHR) has been investigated. The fungus developed white cottony mass on potato dextrose agar and revealed threadlike mycelium under microscope. ITS region analysis of fungus showed its 100\% similarity with Trametes hirsuta. The fungus tolerated temperature from 4 to $48^{\circ} \mathrm{C} \pm 2\left(25^{\circ} \mathrm{C}\right.$ opt.) and $\mathrm{pH} 3-13$ (5-7 opt.). Molecular weight of laccase was determined approximately $45 \mathrm{kDa}$ by native PAGE. Amplification of laccase gene fragment (corresponding to the copper-binding conserved domain) contained $200 \mathrm{bp}$. The optimum $\mathrm{pH}$ for laccase production, at optimum growth temperature, was determined between 5.5 and 7.5. In optimization experiments, fructose and ammonium sulfate were found to be the best carbon and nitrogen sources, respectively, for enhancing the laccase production. Production of laccase was favored by high carbon/nitrogen ratio. Addition of $\mathrm{CuSO}_{4}$ (up to $1.0 \mathrm{mM}$ ) induced laccase production up to 2 -fold, in case of $0.4 \mathrm{mM}$ concentration. Addition of organic solvents also induced the production of laccase; acetone showed the highest (2-fold) induction. The study has implications in bioprospecting of ecologically resilient microbial strains.

\section{Introduction}

Laccases (phenol oxidases; E.C. 1.10.3.2.), also known as multicopper blue oxidases, belong to the oxidoreductase group of enzymes. Biochemically, they are glycoproteins carrying molecular mass between $50 \mathrm{kDa}$ and $130 \mathrm{kDa}[1]$. Fungi, belonging to ascomycetes, deuteromycetes, and basidiomycetes, are known to produce laccases of ecological as well as biotechnological importance, such as biodegradation and bioremediation [1-4]. In addition, laccases are also responsible for various physiological functions in fungi [5]. Due to their broad specificity toward substrate, they can oxidize a range of chemical compounds leading to various industrial applications [6].

Enhancement of laccase production, by modifying the nutritional and physiological conditions during cultivation of promising fungi, is a prerequisite for their optimum utilization at industrial scale. Besides nutritional supplements, inducers like organic solvents and metal ions also play important role in production of laccases $[3,7,8]$. Isolation of new microbial strains of biotechnological applications from various ecological habitats is a prerequisite for industrial growth. The fungi capable of producing laccase at wider temperature and $\mathrm{pH}$ range are likely to play important role in biodegradation under low temperature environments. In the present study, a temperature and $\mathrm{pH}$ tolerant fungus isolated from a glacial site in Indian Himalayan Region (IHR) has been investigated for production of laccase at different physicochemical and nutritional conditions.

\section{Materials and Methods}

2.1. Fungal Strain (GBPI-CDF-03). The fungus was originally isolated from the soil collected from alpine zone of Pindari glacier region $\left(33^{\circ} 5^{\prime}-30^{\circ} 10^{\prime} \mathrm{N}\right.$ to $\left.70^{\circ} 48^{\prime}-79^{\circ} 52^{\prime} \mathrm{E}\right)$, covering altitudes between 3000 and $4500 \mathrm{~m}$ amsl (above mean sea level) of IHR. The mean monthly temperature, at the site, has been reported between $5.5^{\circ} \mathrm{C}$ (January) and $20.1^{\circ} \mathrm{C}$ (August); the soil $\mathrm{pH}$ ranged from 4.5 to 5.1. The description of site has been reported earlier [9-11]. The soil was serially diluted and appropriate dilution was plated using potato dextrose agar (PDA). The pure fungus obtained was maintained on 
PDA slants following subculturing (2 months interval) at $4^{\circ} \mathrm{C}$, in the Microbial Culture Collection established in the Microbiology Laboratory of the Institute. Fresh culture was raised for the experimentation.

2.2. Identification and Characterization of the Fungus. Colony morphology of the fungus was recorded on 5 days old culture, grown on PDA at $25^{\circ} \mathrm{C}$. Four other media, namely, Mycological agar, Czapek dox agar, Sabouraud dextrose maltose agar and Vegetable juice 8 agar (all from Hi Media), were also used for recording the observations on the growth of fungus. Microscopic observations were recorded following lactophenol cotton blue staining (Nikon-Eclipse 50i, Japan). Molecular identification was based on ITS (ITS1-5.8S-ITS2) region analysis using ITS1 and ITS4 primers [12]. The fungal isolate and the gene sequence have been accessioned in Microbial Type Culture Collection and Gene Bank, Institute of Microbial Technology, Chandigarh, India, and NCBI, respectively. The phylogenetic tree was made by using NJ method with the bootstrap value 1000. MEGA 4.0 was used for the phylogenetic analyses (courtesy: A. Sharma, MCC, NCCS, Pune, India).

Temperature tolerance was determined on PDA by incubating the fungal strain between 4 and $50^{\circ} \mathrm{C}(4,9,14,25$, 35,45 , and $50^{\circ} \mathrm{C}$ ), up to two weeks. The $\mathrm{pH}$ tolerance was determined between 1 to $14 \mathrm{pH}$ (with $0.5 \mathrm{pH}$ interval), by incubating the fungus at $25^{\circ} \mathrm{C}$ for one week on $\mathrm{PD}$ agar/broth.

2.3. Medium and Culture Condition for Laccase Production. Laccase production was carried out using modified Kirk and Farrell [13] medium containing (g/L) $2.0 \mathrm{~g}$ malt extract, $2.0 \mathrm{~g}$ glucose, $2.0 \mathrm{~g} \mathrm{NH}_{4} \mathrm{NO}_{3}, 0.26 \mathrm{~g} \mathrm{Na} \mathrm{HPO}_{4}, 0.26 \mathrm{~g} \mathrm{KH}_{2} \mathrm{PO}_{4}$, $0.5 \mathrm{~g} \mathrm{MgSO}_{4}\left(7 \mathrm{H}_{2} \mathrm{O}\right), 0.01 \mathrm{~g} \mathrm{CuSO}_{4}\left(5 \mathrm{H}_{2} \mathrm{O}\right), 0.006 \mathrm{~g} \mathrm{CaCl}_{2}$ $\left(2 \mathrm{H}_{2} \mathrm{O}\right), 0.005 \mathrm{~g} \mathrm{FeSO}_{4}\left(7 \mathrm{H}_{2} \mathrm{O}\right), 0.0005 \mathrm{~g} \mathrm{ZnSO}_{4}\left(7 \mathrm{H}_{2} \mathrm{O}\right)$, $0.00002 \mathrm{~g} \mathrm{Na}_{2} \mathrm{MoO}_{4}, 0.00009 \mathrm{~g} \mathrm{MnSO}_{4} \cdot \mathrm{H}_{2} \mathrm{O}$, and $0.00007 \mathrm{~g}$ $\mathrm{H}_{3} \mathrm{BO}_{3}$. Qualitative plate based estimation was done on the aforesaid medium supplemented with $0.30 \mathrm{~g}$ ABTS (2, $2^{\prime}$-azino-bis 3-ethylbenzothiazoline-6-sulphonic acid). The plate assays were carried out at 6 different temperatures (4, 9, $15,25,35$, and $45^{\circ} \mathrm{C}$ ). Ligninolytic efficiency was determined as ABTS zone to fungal colony diameter ratio * 100. DMP, syringaldazine, and guaiacol (separately) were also used in plate assays for determination of the oxidizing ability of laccase. In quantitative estimations, $50 \mathrm{~mL}$ medium was prepared in $250 \mathrm{~mL}$ Erlenmeyer flasks, without supplementing ABTS. The $\mathrm{pH}$ of the medium was set at $5.5 \pm 0.2$, before autoclaving. Autoclaved medium was inoculated with $5 \mathrm{~mm}$ disc (per flask) of 6-day old fungus culture. The experiments were conducted under static conditions.

2.4. Determination of Molecular Weight of Laccase. The crude enzyme (filtrate) was precipitated with ammonium sulfate up to $70 \%$ saturation and centrifuged at $15000 * \mathrm{~g}$ RCF for $10 \mathrm{~min}$ at $4^{\circ} \mathrm{C}$. Pellets were resuspended in citrate-phosphate $(\mathrm{pH}=2.6)$ buffer. PAGE without SDS was carried out following standard method described by Laemmli [14], using $15 \%$ separating and $4 \%$ stacking gel. Polyacrylamide gel was stained with $1.0 \%$ of ABTS solution prepared in citratephosphate buffer ( $\mathrm{pH}$ 2.6), following $1 \mathrm{~h}$ incubation at room temperature. Pre-stained protein marker (Puregene) was used for determination of molecular weight of the enzyme.

2.5. Molecular Studies on Partial Sequence of Laccase Gene. Laccase gene fragment (corresponding to conserved copper binding domain) was amplified by PCR (BIO-RAD, USA). DNA isolation was done by the method given by Voigt et al. [15]. PCR amplification was carried out using basidiomycetes specific laccase primers Cu1F and Cu2R [16]. $25 \mu \mathrm{L}$ PCR reaction contained $2 \mathrm{X}$ reaction buffer $12.5 \mu \mathrm{L}$, sterile water $6.2 \mu \mathrm{L}, \mathrm{dNTP}\left(10 \mathrm{mM}\right.$ of each dNTP) $2.5 \mu \mathrm{L}, \mathrm{MgCl}_{2}(25 \mathrm{mM})$ $1.5 \mu \mathrm{L}$, forward and reverse primer $1.0 \mu \mathrm{L}$ (10 pmole $/ \mu \mathrm{L}$ each), and Taq DNA polymerase $(3 \mathrm{U} / \mu \mathrm{L}) 0.3 \mu \mathrm{L}$ (dNTP, $\mathrm{MgCl}_{2}$, and Taq DNA polymerase) from Fermentas Life Science. The PCR conditions were initial denaturation: $94^{\circ} \mathrm{C}$ for $3 \mathrm{~min}$, denaturation: $94^{\circ} \mathrm{C}$ for $30 \mathrm{~s}$, annealing: $48^{\circ} \mathrm{C}$ for $45 \mathrm{~s}$, extension: $72^{\circ} \mathrm{C}$ for $3 \mathrm{~min}$, final extension: $72^{\circ} \mathrm{C}$ for $10 \mathrm{~min}$, and total cycles: 35 . Molecular weight of amplified product was analyzed on agarose gel $(0.8 \%)$.

2.6. Effect of Physicochemical and Nutritional Parameters and Other Supplements on Laccase Production. Production of laccase was determined at 4 temperatures $(15,25,35$, and $45^{\circ} \mathrm{C}$ ) at every $3 \mathrm{rd}$ day, up to 15 days of incubation. Laccase production with respect to $\mathrm{pH}$ was determined by inoculating the broth, set at different $\mathrm{pH}$, ranging from 3.5 to 11.5 (with an interval of 2 units).

Six carbon, glucose (control), fructose, maltose, sucrose, starch and cellulose, 5 nitrogen sources (ammonium nitrate (control), ammonium sulfate, ammonium ferrous sulfate, potassium nitrate, and urea), and one set without inorganic nitrogen at $0.2 \%$ level were used for enhancing the production of laccase. All the carbon and nitrogen sources were from $\mathrm{Hi}$ Media. Effect of the best carbon and nitrogen sources was further determined by increasing the concentration level up to $1.0 \%$.

In other supplements category, 4 organic solvents namely, methanol, ethanol, isopropanol, and acetone ( $0.2 \%$ /supplemented at day 4 of incubation), were tested as inducers. Effect of $\mathrm{CuSO}_{4}$ concentration $(0.2$ to $1.0 \mathrm{mM}$ /supplemented at day 4 of incubation) was also determined.

These experiments (effect of $\mathrm{pH}$, carbon sources, nitrogen sources, $\mathrm{CuSO}_{4}$, and solvents) were carried out at $25^{\circ} \mathrm{C}$, following 12 days of incubation under static conditions.

2.7. Enzyme Assay. Laccase activity was determined in terms of oxidation of ABTS using spectrophotometer (Amersham Bioscience Ultrospec 2100 pro) [17]. The fungal culture was filtered with Whatman No. 1 filter paper and used as crude enzyme. Mycelium, collected and dried at $65^{\circ} \mathrm{C}$ for $72 \mathrm{~h}$, was used for determination of biomass. Reaction mixture was prepared with citrate-phosphate buffer $(\mathrm{pH}=2.6), 2.0 \mathrm{mM}$ ABTS, and the crude enzyme. Absorbance was recorded at $420 \mathrm{~nm}$, following $2 \mathrm{~min}$ of incubation at room temperature. Laccase activity was calculated using extinction coefficient $=$ $36000 \mathrm{M}^{-1} \mathrm{~cm}^{-1}$ [18]. 1 unit of enzyme activity is defined as 
$1 \mu \mathrm{M}$ of ABTS oxidized per min. Protein was also determined following the method of Lowry et al. [19].

\section{Results}

The fungus (GBPI-CDF-03) developed white cottony mass on all the 5 media used, with growth being more compact on Vegetable juice 8 agar. Microscopy revealed presence of thread-like septate mycelium without any reproductive structures (Figure 1(a)). The fungus tolerated wide range of temperature $\left(4-48 \pm 2^{\circ} \mathrm{C}\right.$, optimum $\left.25 \pm 2^{\circ} \mathrm{C}\right)$ and $\mathrm{pH}$ (3.0-13.0 pH, optimum between 5 and 7). ITS region based molecular identification revealed its maximum similarity with Trametes hirsuta. Growth requirements along with the phenotypic and genotypic characters and the phylogenetic relationship of the fungus are presented in Table 1 and Figure 2. The accessions given to fungus and the nucleotide sequence are MTCC 11397 and JX910367, respectively.

In plate assays, conducted at optimum growth conditions, the fungus oxidized ABTS and developed green colour around the colony indicating the production of laccase (Figure 1(b)). The fungus also produced laccase through oxidation of other three substrates, namely, guaiacol, syringaldazine, and DMP. ABTS, however, was found to exhibit highest sensitivity towards laccase activity. At suboptimal temperatures $\left(4,9,15,35\right.$, and $\left.45^{\circ} \mathrm{C}\right)$, maximum ligninolytic efficiency (ABTS zone to colony dia) was observed at $4^{\circ} \mathrm{C}$. The efficiency for production of ligninolytic enzymes was found to be inversely proportional to the temperature (Table 2). Molecular weight of laccase was determined to be approximately $45 \mathrm{kDa}$ (Figure 3), while the PCR amplified sequence of laccase gene fragment (corresponding to copper binding domain) was obtained approximately of $200 \mathrm{bp}$ size. In quantitative estimations conducted at $15,25,35$, and $45^{\circ} \mathrm{C}$, production of laccase, fungal biomass, and total protein content varied with culture conditions. Maximum laccase production $(394.5 \mathrm{U} / \mathrm{L})$ was recorded at $35^{\circ} \mathrm{C}$ on day 12 of incubation. In this case, the highest biomass $(22.8 \mathrm{mg} / 50 \mathrm{~mL})$ and maximum protein $(51.1 \mu \mathrm{g} / \mathrm{mL})$ were recorded on day 12 and 15 , respectively. Laccase production was recorded minimum $(269.7 \mathrm{U} / \mathrm{L})$ at $25^{\circ} \mathrm{C}$ with maximum fungal biomass $(25.6 \mathrm{mg} / 50 \mathrm{~mL})$ and protein concentration $(41.9 \mu \mathrm{g} / \mathrm{mL})$, at day 12 of incubation. Slightly increased production of laccase $(272 \mathrm{U} / \mathrm{L})$ was recorded at $15^{\circ} \mathrm{C}$ with fungal biomass $(14.4 \mathrm{mg} / 50 \mathrm{~mL})$ and protein content $(66.2 \mu \mathrm{g} / \mathrm{mL})$, at day 12 of incubation (Table 3, Figures 4(a), 4(b), and 4(c)). The activity at $45^{\circ} \mathrm{C}$ was estimated to be $282.1 \mathrm{U} / \mathrm{L}$ with very little biomass $(8.0 \mathrm{mg} / 50 \mathrm{~mL})$ and protein content $(16.8 \mu \mathrm{g} / \mathrm{mL})$, at day 12 of incubation (not presented in the Figures). While the production of laccase was recorded between $\mathrm{pH} 3.5$ and 11.5, the maximum production $(270 \mathrm{U} / \mathrm{L})$ along with biomass and the protein content was favoured at $\mathrm{pH}$ between 5.5 and 7.5 (Table 4, Figure 5).

Among 6 carbon sources $(0.2 \%)$, fructose was found to increase the production of laccase along with higher protein content and reduced fungal biomass, in comparison to control (Table 5, Figure 6(a)). The laccase production increased with the increase of fructose concentration up to $1.0 \%$, maximum being at $0.4 \%$ concentration of fructose
TABLE 1: Morphological and molecular characteristics of the fungus (GBPI-CDF-03).

\begin{tabular}{ll}
\hline Character & Description \\
\hline $\begin{array}{l}\text { Colony morphology } \\
\text { (on PD agar) }\end{array}$ & $\begin{array}{l}\text { White cottony mass with no } \\
\text { exudation or pigmentation }\end{array}$ \\
\hline Microscopic features & $\begin{array}{l}\text { Thread like mycelium with septa } \\
\text { showing the characteristic feature of } \\
\text { upper fungi }\end{array}$ \\
\hline & $\begin{array}{l}\text { Temperature requirement between } \\
4 \text { and } 48^{\circ} \mathrm{C} \text { (optimum 25 } \mathrm{C} \text { ), pH } \\
\text { requirement between 3 and 13 } \\
\text { (optimum 5-7) }\end{array}$ \\
Growth characters & $\begin{array}{l}\text { Maximum similarity (100\%) with } \\
\text { Trametes hirsuta (JF439511) }\end{array}$ \\
\hline $\begin{array}{l}\text { Phylogenetic relationship } \\
\text { (ITS region analysis) } \\
\text { Culture accession no. } \\
\text { Nucleotide sequence } \\
\text { accession no. }\end{array}$ & $\begin{array}{l}\text { MTCC 11397 } \\
\text { JX910367 }\end{array}$ \\
\hline
\end{tabular}

TABLE 2: Ligninolytic efficiency of the fungus (GBPI-CDF-03) at different temperatures.

\begin{tabular}{lcccc}
\hline $\begin{array}{l}\text { Temperature } \\
\left({ }^{\circ} \mathrm{C}\right)\end{array}$ & $\begin{array}{c}\text { Incubation } \\
\text { time } \\
\text { (days) }\end{array}$ & $\begin{array}{c}\text { ABTS zone } \\
\text { dia }(\mathrm{mm}) \\
(\mathrm{ZD})\end{array}$ & $\begin{array}{c}\text { Fungal } \\
\text { colony } \\
\text { dia }(\mathrm{mm}) \\
(\mathrm{CD})\end{array}$ & $\begin{array}{c}\text { Ligninolytic } \\
\text { efficiency }= \\
\text { ZD/CD } * 100\end{array}$ \\
\hline 4 & 21 & 22 & 5 & 440 \\
9 & 21 & 19 & 7 & 271 \\
15 & 14 & 15 & 10 & 150 \\
25 & 7 & 10 & 50 & 20 \\
35 & 7 & 12 & 46 & 26 \\
45 & 7 & 8 & 15 & 53 \\
\hline
\end{tabular}

Dia: diameter.

(2:1 carbon/nitrogen ratio) (Table 6). However, the increase in biomass and protein continued up to $1.0 \%$ fructose concentration. Other carbon sources (maltose, sucrose, starch, and cellulose) were found to be inhibitory for laccase production as well as the production of fungal biomass. Cellulose was found to be the most inhibitory carbon source, followed by starch, sucrose, and maltose. Among five nitrogen sources, ammonium sulfate was found to be the best at $0.2 \%$ for production of laccase and the protein content (Table 5, Figure 6(b)). Further increment in ammonium sulfate concentration was found to be inhibitory for laccase production (Table 6). Effect of ammonium ferrous sulfate was found to be at par to the control (ammonium nitrate). Presence of other nitrogen sources (urea and potassium nitrate) and also the case without any nitrogen source were found to reduce the production of laccase.

Addition of $\mathrm{CuSO}_{4}$ increased laccase production along with production of protein content up to 2 -fold in comparison to control, maximum being in case of $0.4 \mathrm{mM}$ concentration. Further increment in $\mathrm{CuSO}_{4}$ (up to $1.0 \mathrm{mM}$ ) resulted in decline of laccase production, although, the decreased values were higher in comparison to control (Figure 6(c), Table 7). Other inducers, the low molecular weight organic solvents at $0.2 \%$ concentration, were also found to enhance the 


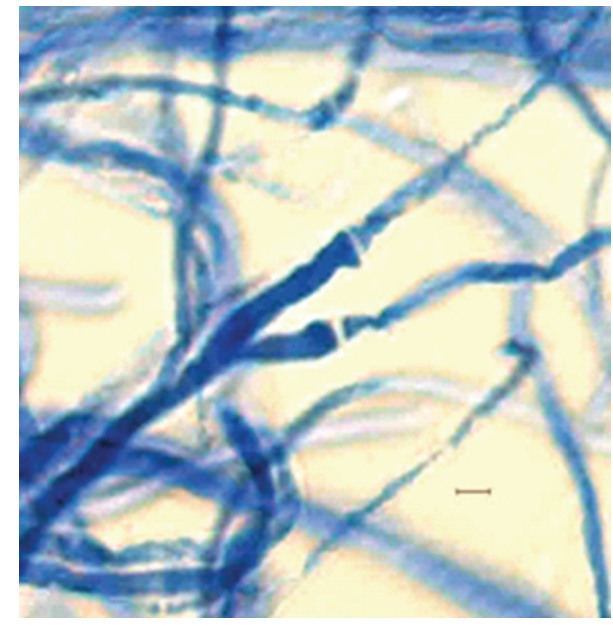

(a)

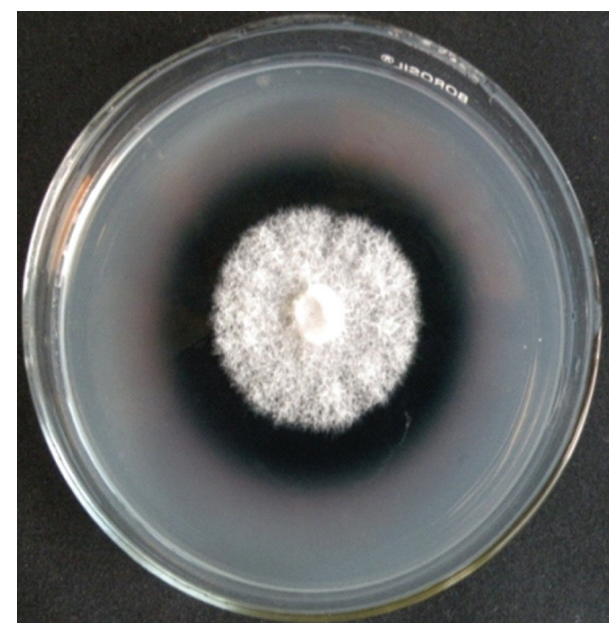

(b)

FIGURE 1: (a) Microscopic features of the fungus ( $\mathrm{Bar}=2 \mu \mathrm{m}$ ); (b) laccase production on ABTS plate.

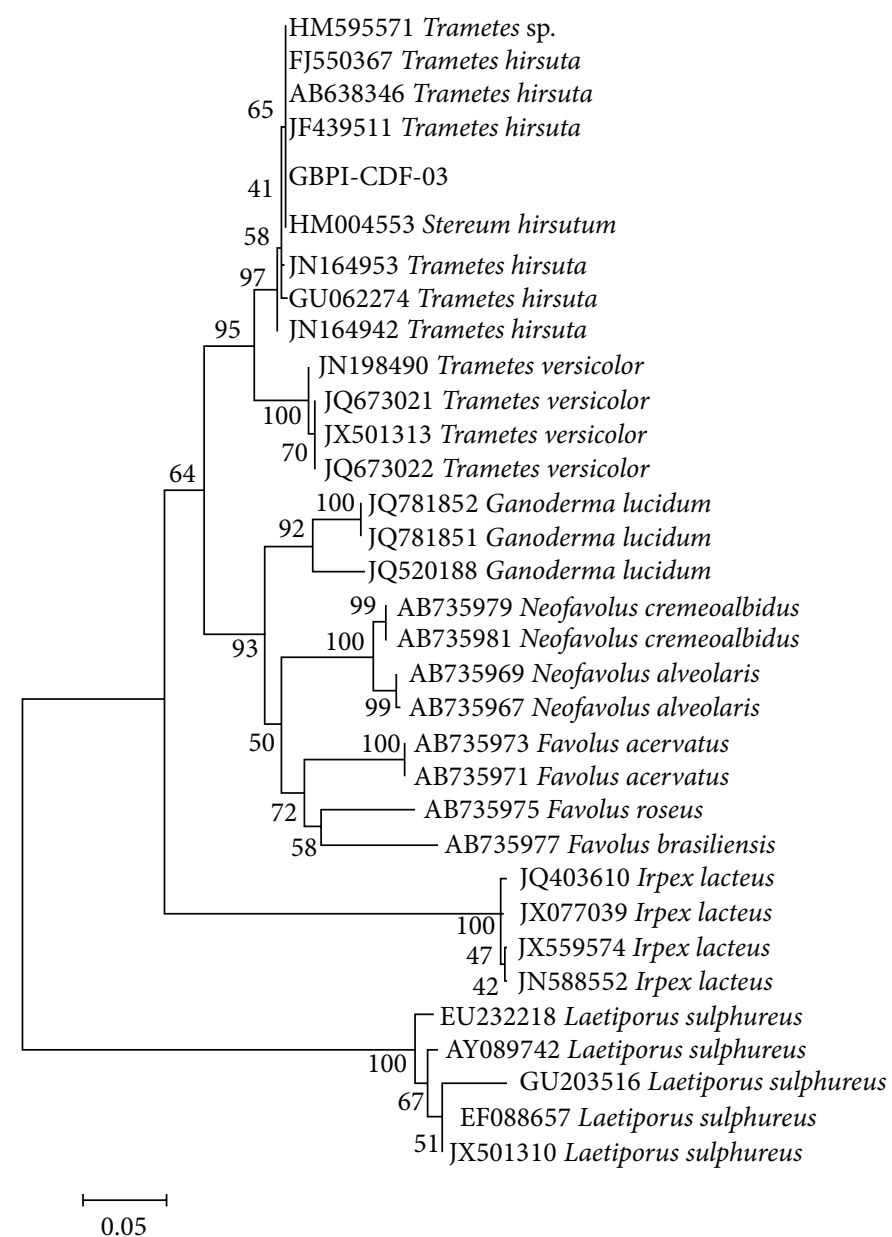

FIGURE 2: Phylogenetic relationship of the fungus. 
Table 3: Production of fungal biomass and protein content at different temperatures.

\begin{tabular}{|c|c|c|c|c|c|c|}
\hline \multirow{3}{*}{$\begin{array}{l}\text { Incubation time } \\
\text { (days) }\end{array}$} & \multicolumn{6}{|c|}{ Temperature $\left({ }^{\circ} \mathrm{C}\right)$} \\
\hline & \multicolumn{2}{|c|}{15} & \multicolumn{2}{|c|}{25} & \multicolumn{2}{|c|}{35} \\
\hline & $\begin{array}{c}\text { Biomass } \\
(\mathrm{mg} / 50 \mathrm{~mL})\end{array}$ & $\begin{array}{l}\text { Protein } \\
(\mu \mathrm{g} / \mathrm{mL})\end{array}$ & $\begin{array}{c}\text { Biomass } \\
(\mathrm{mg} / 50 \mathrm{~mL})\end{array}$ & $\begin{array}{l}\text { Protein } \\
(\mu \mathrm{g} / \mathrm{mL})\end{array}$ & $\begin{array}{c}\text { Biomass } \\
(\mathrm{mg} / 50 \mathrm{~mL})\end{array}$ & $\begin{array}{c}\text { Protein } \\
(\mu \mathrm{g} / \mathrm{mL})\end{array}$ \\
\hline 3 & $4.1 \pm 0.5$ & $36.4 \pm 3.1$ & $8.6 \pm 1.6$ & $34.4 \pm 6.6$ & $5.3 \pm 1.1$ & $34.6 \pm 5.0$ \\
\hline 6 & $7.6 \pm 0.8$ & $44.6 \pm 10.7$ & $13.0 \pm 3.2$ & $36.9 \pm 8.2$ & $13.6 \pm 2.0$ & $39.4 \pm 4.0$ \\
\hline 9 & $11.5 \pm 2.0$ & $54.6 \pm 4.4$ & $17.9 \pm 6.2$ & $32.9 \pm 4.1$ & $18.7 \pm 4.4$ & $42.9 \pm 8.0$ \\
\hline 12 & $14.4 \pm 2.2$ & $66.2 \pm 5.7$ & $25.6 \pm 4.2$ & $41.9 \pm 6.7$ & $22.8 \pm 2.8$ & $43.6 \pm 5.5$ \\
\hline 15 & $17.9 \pm 3.4$ & $68.3 \pm 5.8$ & $19.8 \pm 4.0$ & $33.8 \pm 5.5$ & $19.3 \pm 2.4$ & $51.1 \pm 8.8$ \\
\hline
\end{tabular}

Values are mean $\pm \mathrm{SD}(n=3)$.

TABLe 4: Production of fungal biomass and protein content at different $\mathrm{pH}$.

\begin{tabular}{lcc}
\hline $\mathrm{pH}$ & Biomass $(\mathrm{mg} / 50 \mathrm{~mL})$ & Protein $(\mu \mathrm{g} / \mathrm{mL})$ \\
\hline 3.5 & $15.3 \pm 3.5$ & $19.6 \pm 3.9$ \\
5.5 & $24.3 \pm 4.5$ & $28.0 \pm 2.1$ \\
7.5 & $21.3 \pm 3.0$ & $35.1 \pm 4.4$ \\
9.5 & $14.0 \pm 2.0$ & $30.9 \pm 2.8$ \\
11.5 & $8.4 \pm 2.6$ & $11.12 \pm 2.9$ \\
\hline
\end{tabular}

Values are mean $\pm \mathrm{SD}(n=3)$.

production of laccase, in comparison to control (Figure 6(d), Table 7). Among these, acetone favoured the production of laccase (up to 2 fold induction), with higher protein content. The induction effect, in this case, was recorded up to $0.6 \%$ (Table 8). Addition of acetone did not favor the production of fungal biomass.

\section{Discussion}

The growth characters, such as tolerance to wider range of temperature and $\mathrm{pH}$, are indicative of the ecological resilience possessed by the fungus. Isolation of new fungal strains from low temperature environments possessing similar growth characteristics along a range of biotechnological applications has been reported in recent years [20-25]. Temperature and $\mathrm{pH}$ are two of the most important factors in production of enzymes. Role of suboptimal temperatures, both towards higher as well as lower $\left(15\right.$ and $35^{\circ} \mathrm{C}$, resp.), in enhancing the production of laccase was clearly demonstrated in the present investigation. In both the instances, it coincided with decrease in production of fungal biomass. Varying results, based on the organisms as well as the growth conditions, have been reported by different workers on production of ligninolytic enzymes. Šnajdr and Baldrian [26] reported production of laccase by T. versicolor between 25 and $30^{\circ} \mathrm{C}$, while in a recent study, laccase production has been reported to decrease beyond $28^{\circ} \mathrm{C}$ [27]. Generally, a bell-shaped curve has been reported for laccase activity with respect to $\mathrm{pH}$ [3]. Janusz et al. [28] have reported $\mathrm{pH}$ 7.5, optimum for production of laccase by Rhizoctonia praticola, as an exceptional case. In a recent study on Trametes trogii, $\mathrm{pH} 3$ was found to be optimum for laccase production [29].

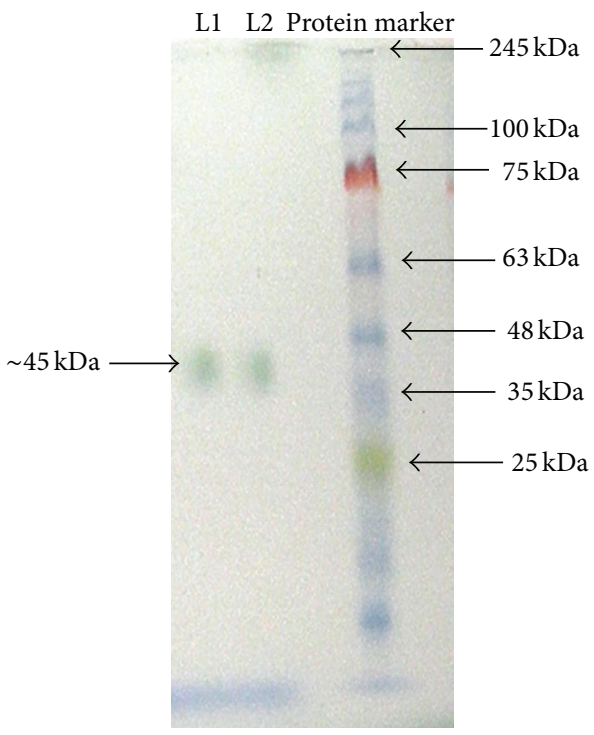

FIgURE 3: Zymogram of laccase (L1 and L2) stained with 1\% ABTS following native PAGE, M-prestained protein marker.

Optimization for enzyme production can be regulated by modifying the nutritional sources, carbon and nitrogen, in particular. Generally, glucose is considered to be the best carbon source for production of enzymes [7]. Production of laccase, favoured by replacing glucose with fructose in the present study, can be attributed to the specific preference for the carbon source by the fungus under study. Similar observation in case of Agaricus sp. has been reported recently by Manimozhi and Kaviyarasan [30]. Among nitrogen sources, ammonium sulfate at $0.2 \%$ concentration gave maximum production of laccase, in the present investigation. Reduction in laccase production, on increasing the ammonium sulfate concentration beyond 1:1 carbon/nitrogen ratio, can be attributed to the fact that nitrogen depletion is likely to favour the production of laccase [31]. In general, high carbon: nitrogen ratio favors the production of laccase, as observed in the present investigation. Contrary to these observations, reverse conditions have also been reported [32].

$\mathrm{CuSO}_{4}$ and some organic solvents are known as inducers for enhancing the laccase activity. In the present investigation, $\mathrm{CuSO}_{4}$ induced laccase production, almost up to 2 fold, over control. Inducing effect of $\mathrm{CuSO}_{4}$ has also been reported 
TABLE 5: Production of fungal biomass and protein content in presence of different carbon and nitrogen sources.

\begin{tabular}{lccccc}
\hline Carbon source $(0.2 \%)$ & Biomass $(\mathrm{mg} / 50 \mathrm{~mL})$ & Protein $(\mu \mathrm{g} / \mathrm{mL})$ & Nitrogen source $(0.2 \%)$ & Biomass $(\mathrm{mg} / 50 \mathrm{~mL})$ & Protein $(\mu \mathrm{g} / \mathrm{mL})$ \\
\hline Glucose & $24.9 \pm 4.0$ & $27.0 \pm 5.5$ & Absence of nitrogen & $21.0 \pm 2.2$ & $28.6 \pm 4.9$ \\
Fructose & $19.3 \pm 3.0$ & $42.3 \pm 4.0$ & Ammonium nitrate & $28.0 \pm 4.5$ & $34.6 \pm 4.5$ \\
Maltose & $15.6 \pm 4.0$ & $33.6 \pm 5.5$ & Ammonium sulfate & $23.0 \pm 3.6$ & $40.0 \pm 5.0$ \\
Sucrose & $11.3 \pm 2.6$ & $39.0 \pm 6.5$ & Ammonium ferrous sulfate & $18.5 \pm 2.5$ & $38.3 \pm 4.5$ \\
Starch & $10.5 \pm 1.8$ & $31.6 \pm 5.1$ & Potassium nitrate & $25.1 \pm 4.5$ & $19.6 \pm 3.2$ \\
Cellulose & $9.5 \pm 1.0$ & $26.1 \pm 7.6$ & Urea & $16.4 \pm 4.1$ & $41.6 \pm 4.0$ \\
\hline
\end{tabular}

Values are mean $\pm \mathrm{SD}(n=3)$.

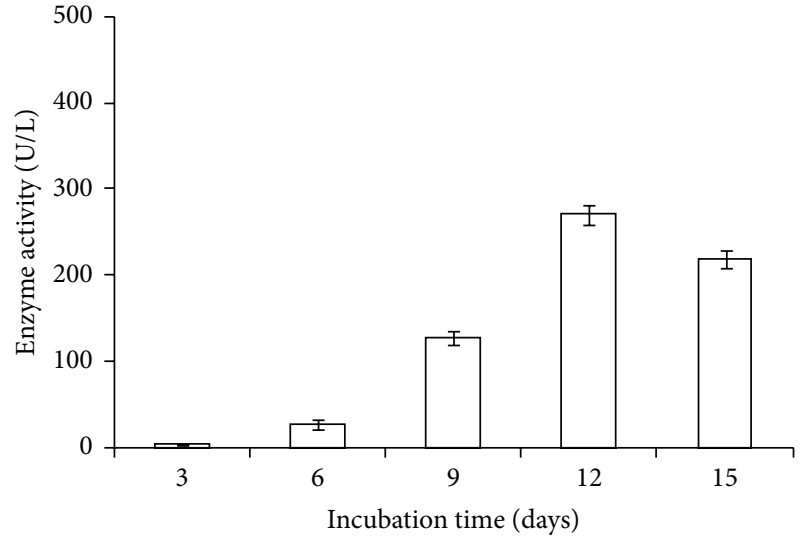

(a) $15^{\circ} \mathrm{C}$

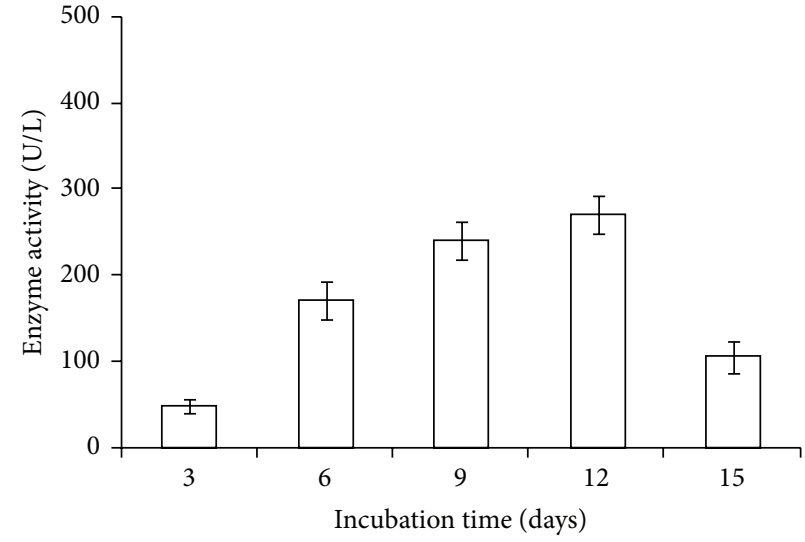

(b) $25^{\circ} \mathrm{C}$

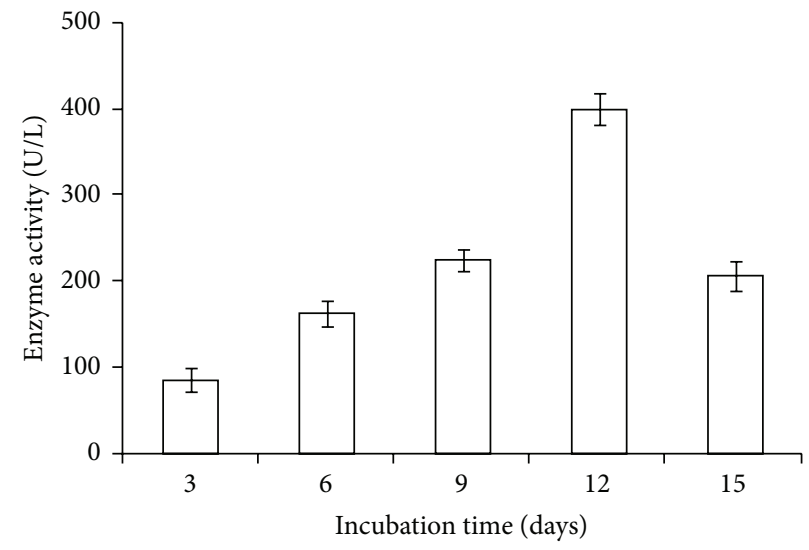

(c) $35^{\circ} \mathrm{C}$

FIGURE 4: Effect of different temperatures with respective time on laccase production: (a) $15^{\circ} \mathrm{C}$, (b) $25^{\circ} \mathrm{C}$, (c) $35^{\circ} \mathrm{C}$.

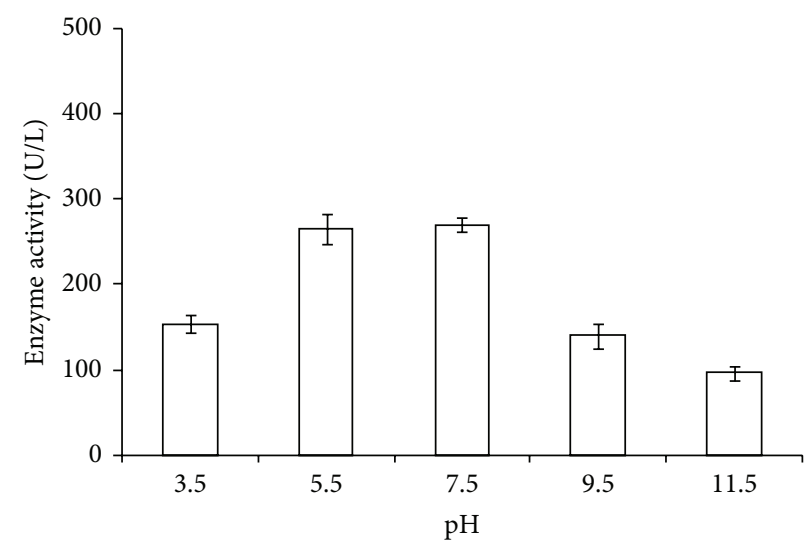

Figure 5: Effect of $\mathrm{pH}$ on laccase production. 
TABLE 6: Laccase activity, fungal biomass, and protein content with different concentrations of fructose and ammonium sulfate.

\begin{tabular}{lccccccc}
\hline $\begin{array}{l}\text { Fructose } \\
(\%)\end{array}$ & $\begin{array}{c}\text { Laccase } \\
(\mathrm{U} / \mathrm{L})\end{array}$ & $\begin{array}{c}\text { Biomass } \\
(\mathrm{mg} / 50 \mathrm{~mL})\end{array}$ & $\begin{array}{c}\text { Protein } \\
(\mu \mathrm{g} / \mathrm{mL})\end{array}$ & $\begin{array}{c}\text { Ammonium } \\
\text { sulfate }(\%)\end{array}$ & $\begin{array}{c}\text { Laccase } \\
(\mathrm{U} / \mathrm{L})\end{array}$ & $\begin{array}{c}\text { Biomass } \\
(\mathrm{mg} / 50 \mathrm{~mL})\end{array}$ & $\begin{array}{c}\text { Protein } \\
(\mu \mathrm{g} / \mathrm{mL})\end{array}$ \\
\hline Control & $248.0 \pm 6.5$ & $22.4 \pm 6.8$ & $31.6 \pm 4.0$ & Control & $260.0 \pm 8.9$ & $26.1 \pm 4.4$ & $22.3 \pm 4.9$ \\
$0.2(1: 1)$ & $335.0 \pm 14.3$ & $28.7 \pm 1.5$ & $45.2 \pm 6.6$ & $0.2(1: 1)$ & $344.0 \pm 14.1$ & $29.6 \pm 4.5$ & $38.3 \pm 8.5$ \\
$0.4(2: 1)$ & $435.0 \pm 35.5$ & $31.8 \pm 3.6$ & $65.3 \pm 8.7$ & $0.4(1: 2)$ & $194.0 \pm 23.6$ & $27.2 \pm 4.4$ & $33.6 \pm 7.7$ \\
$0.6(3: 1)$ & $374.0 \pm 31.2$ & $34.3 \pm 4.0$ & $69.6 \pm 4.5$ & $0.6(1: 3)$ & $154.0 \pm 4.7$ & $25.5 \pm 2.2$ & $32.3 \pm 3.7$ \\
$0.8(4: 1)$ & $336.0 \pm 11.8$ & $36.5 \pm 3.4$ & $84.3 \pm 10.0$ & $0.8(1: 4)$ & $133.0 \pm 7.1$ & $24.6 \pm 5.0$ & $30.6 \pm 3.5$ \\
$1.0(5: 1)$ & $310.0 \pm 9.4$ & $37.3 \pm 4.5$ & $108.6 \pm 13.3$ & $1.0(1: 5)$ & $130.0 \pm 3.3$ & $25.8 \pm 4.9$ & $26.0 \pm 4.3$ \\
\hline
\end{tabular}

Values given in parentheses depict the carbon/nitrogen ratio; values are mean $\pm \mathrm{SD}(n=3)$.

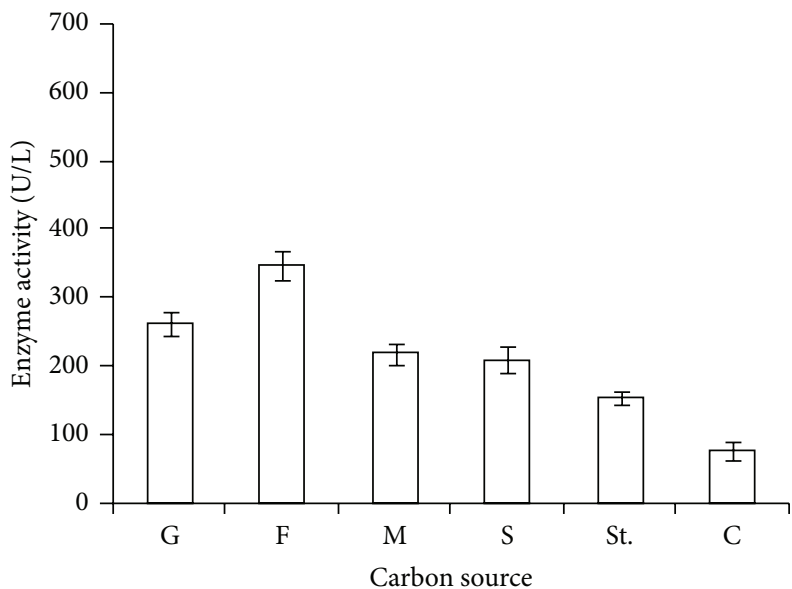

(a)

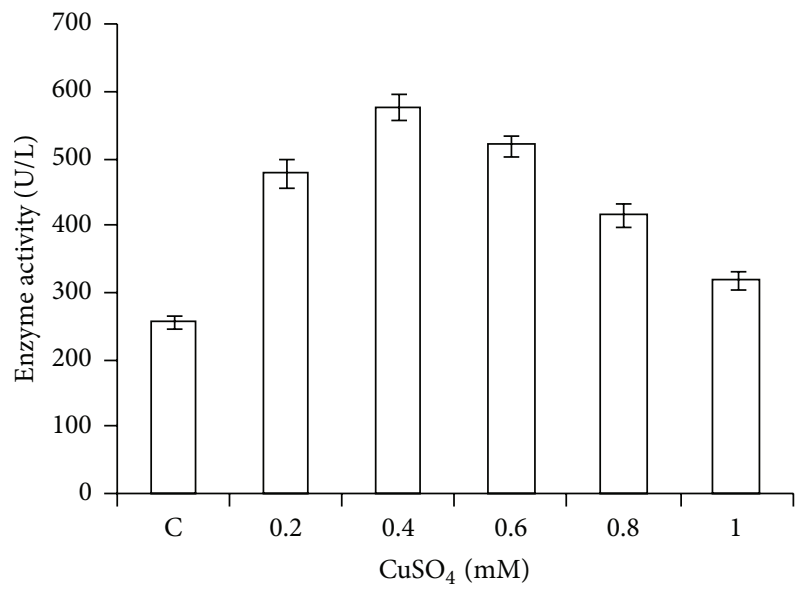

(c)

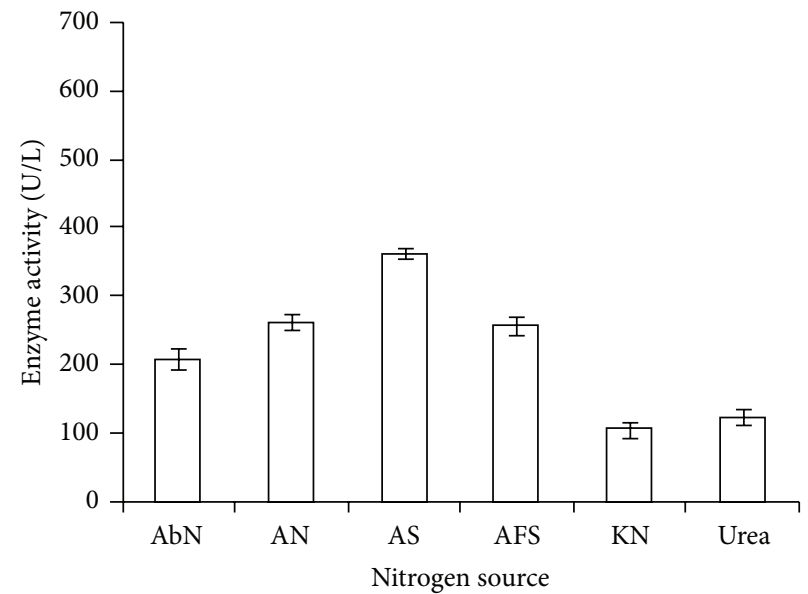

(b)

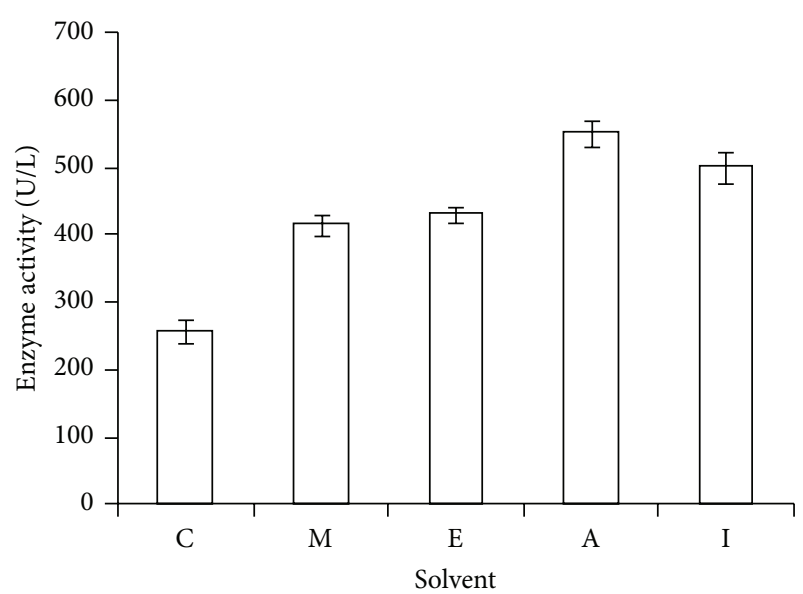

(d)

FiguRE 6: Effect of nutritional parameters on laccase production: (a) carbon sources: G (glucose), F (fructose), M (maltose), S (sucrose), St. (starch), C (cellulose); (b) nitrogen sources: AbN (absence of inorganic nitrogen), AN (ammonium nitrate), AS (ammonium sulfate), AFS (ammonium ferrous sulfate), $\mathrm{KN}$ (potassium nitrate); (c) $\mathrm{CuSO}_{4}$ concentration (0.2 to $1.0 \mathrm{mM}$ ) (d) organic solvents: C (control), $\mathrm{M}$ (methanol), E (ethanol), A (acetone), I (iso-propanol).

in earlier studies in T. hirsuta. $\mathrm{CuSO}_{4}$ is a constituent of the catalytic center of the laccase; hence it is important for the synthesis of the respective enzyme [33]. Importance of copper in regulation of laccase production at transcriptional levels has also been reported [7]. Enhancement in laccase production, in the present investigation, due to addition of organic solvents, such as, methanol, ethanol, acetone, and isopropanol, is also an important finding. The increase in laccase production by ethanol has been observed in earlier studies [34]. The purpose of using simple organic solvents for induction is to increase the ecological and economical value of the process. 
TABLE 7: Production of fungal biomass and protein content in presence of different concentrations of $\mathrm{CuSO}_{4}$ and different solvents $(0.2 \%)$.

\begin{tabular}{lccccc}
\hline $\mathrm{CuSO}_{4}(\mathrm{mM})$ & Biomass $(\mathrm{mg} / 50 \mathrm{~mL})$ & Protein $(\mu \mathrm{g} / \mathrm{mL})$ & Solvent $(0.2 \%)$ & Biomass $(\mathrm{mg} / 50 \mathrm{~mL})$ & Protein $(\mu \mathrm{g} / \mathrm{mL})$ \\
\hline 0.2 & $16.8 \pm 2.5$ & $35.6 \pm 6.6$ & Control & $25.3 \pm 3.0$ & $23.9 \pm 3.4$ \\
0.4 & $13.1 \pm 3.3$ & $44.0 \pm 6.5$ & Methanol & $16.1 \pm 3.6$ & $38.1 \pm 4.0$ \\
0.6 & $11.7 \pm 0.9$ & $46.6 \pm 7.0$ & Ethanol & $16.6 \pm 2.0$ & $41.8 \pm 5.7$ \\
0.8 & $8.3 \pm 3.0$ & $54.0 \pm 5.5$ & Acetone & $18.4 \pm 2.2$ & $45.2 \pm 6.1$ \\
1.0 & $7.1 \pm 2.5$ & $55.1 \pm 7.2$ & Isopropanol & $13.0 \pm 2.5$ & $38.3 \pm 5.6$ \\
\hline
\end{tabular}

Control value for biomass $=24.0 \pm 3.8$, and protein $=31.2 \pm 2.5$; values are mean $\pm \mathrm{SD}(n=3)$.

TABLE 8: Laccase activity, fungal biomass, and protein content with different concentrations of acetone.

\begin{tabular}{lccc}
\hline $\begin{array}{l}\text { Acetone } \\
(\%)\end{array}$ & $\begin{array}{c}\text { Laccase } \\
(\mathrm{U} / \mathrm{L})\end{array}$ & $\begin{array}{c}\text { Biomass } \\
(\mathrm{mg} / 50 \mathrm{~mL})\end{array}$ & $\begin{array}{c}\text { Protein } \\
(\mu \mathrm{g} / \mathrm{mL})\end{array}$ \\
\hline Control & $263 \pm 9.4$ & $21.8 \pm 3.8$ & $25.1 \pm 3.6$ \\
0.2 & $542 \pm 1.6$ & $17.7 \pm 1.5$ & $45.4 \pm 5.9$ \\
0.4 & $397 \pm 1.4$ & $17.0 \pm 3.0$ & $41.1 \pm 6.0$ \\
0.6 & $349 \pm 1.0$ & $16.3 \pm 4.0$ & $41.0 \pm 6.0$ \\
0.8 & $227 \pm 1.1$ & $13.3 \pm 3.5$ & $35.7 \pm 4.5$ \\
1.0 & $201 \pm 1.7$ & $11.0 \pm 3.0$ & $31.5 \pm 4.0$ \\
\hline
\end{tabular}

Values are mean $\pm \mathrm{SD}(n=3)$.

\section{Conclusion}

It can be concluded that increased production of laccase at suboptimal conditions, as recorded in the present study, is likely to be advantageous from ecological as well as biotechnological prospects. Temperature tolerant organisms, psychrotolerant ones in particular, can be presumed for their contributions in biodegradation in low temperature environments. High yield, consistent production, and sustainability of secondary metabolites under stress conditions will be important parameters in such investigations. The fungus (GBPI-CDF-03) produced laccase under wide range of temperature covering psychrophilic to mesophilic range, also touching the thermophilic range. The present investigation emphasizes the importance of isolation and identification of new and efficient microbial strains from the extreme environments of IHR for production of industrially desired biomolecules [35]. The findings of the present study, based on the identification of a laccase producing fungal strain, followed by the optimization for nutritional and physiological conditions, are likely to be useful in further upgrade of the process.

\section{Acknowledgments}

The director of G. B. Pant Institute of Himalayan Environment and Development, Almora, is gratefully acknowledged for extending the facilities. Ministry of Environment and Forests, Government of India, is thanked for financial support. Senior author is thankful to the Indian Council of Medical Research (ICMR), Government of India, New Delhi, for awarding the research fellowship.

\section{References}

[1] O. V. Morozova, G. P. Shumakovich, M. A. Gorbacheva, S. V. Shleev, and A. I. Yaropolov, "Blue laccases," Biochemistry, vol. 72, no. 10, pp. 1136-1150, 2007.

[2] S. S. Desai and C. Nityanand, "Microbial laccases and their applications: a review," Asian Journal of Biotechnology, vol. 3, no. 2, pp. 98-124, 2011.

[3] Shraddha, R. Shekher, S. Sehgal, M. Kamthania, and A. Kumar, "Laccase: microbial sources, production, purification, and potential biotechnological applications," Enzyme Research, vol. 2011, Article ID 217861, 11 pages, 2011.

[4] A. M. Mayer and R. C. Staples, "Laccase: new functions for an old enzyme," Phytochemistry, vol. 60, no. 6, pp. 551-565, 2002.

[5] H. Claus, "Laccases: structure, reactions, distribution," Micron, vol. 35, no. 1-2, pp. 93-96, 2004.

[6] A. Kunamneni, A. Ballesteros, F. J. Plou, and M. Alcalde, "Fungal laccase-a versatile enzyme for biotechnological applications," in CommunicatIng Current Research and Educational Topics and Trends In Applied Microbiology, A. Mendez-Vilas, Ed., pp. 233-245, Formex, Badajoz, Spain, 2007.

[7] A. Piscitelli, P. Giardina, V. Lettera, C. Pezzella, G. Sannia, and V. Faraco, "Induction and transcriptional regulation of laccases in fungi," Current Genomics, vol. 12, no. 2, pp. 104-112, 2011.

[8] K. Brijwani, A. Rigdon, and P. V. Vadlani, "Fungal laccases: production, function, and applications in food processing," Enzyme Research, vol. 2010, Article ID 149748, 10 pages, 2010.

[9] B. Chaurasia, A. Pandey, and L. M. S. Palni, "Distribution, colonization and diversity of arbuscular mycorrhizal fungi associated with central Himalayan rhododendrons," Forest Ecology and Management, vol. 207, no. 3, pp. 315-324, 2005.

[10] A. Pandey and L. M. S. Palni, "The rhizosphere effect in trees of the Indian Central Himalaya with special reference to altitude," Applied Ecology and Environmental Research, vol. 5, no. 1, pp. 93-102, 2007.

[11] M. K. Malviya, A. Pandey, P. Trivedi, G. Gupta, and B. Kumar, "Chitinolytic activity of cold tolerant antagonistic species of streptomyces isolated from glacial sites of Indian Himalaya," Current Microbiology, vol. 59, no. 5, pp. 502-508, 2009.

[12] T. J. White, T. D. Bruns, S. B. Lee, and J. W. Taylor, "Amplification and direct sequencing of fungal ribosomal RNA genes for phylogenetics," in PCR Protocols: A Guide To Methods and Applications, M. A. Innis, D. H. Gelfand, J. J. Sninsky, and T. J. White, Eds., pp. 315-322, Academic Press, San Diego, Calif, USA, 1990.

[13] T. K. Kirk and R. L. Farrell, "Enzymatic "combustion": the microbial degradation of lignin," Annual Review of Microbiology, vol. 41, pp. 465-505, 1987. 
[14] U. K. Laemmli, "Cleavage of structural proteins during the assembly of the head of bacteriophage T4," Nature, vol. 227, no. 5259, pp. 680-685, 1970.

[15] K. Voigt, E. Cigelnik, and K. O’Donnell, "Phylogeny and PCR identification of clinically important zygomycetes based on nuclear ribosomal-DNA sequence data," Journal of Clinical Microbiology, vol. 37, no. 12, pp. 3957-3964, 1999.

[16] P. Luis, G. Walther, H. Kellner, F. Martin, and F. Buscot, "Diversity of laccase genes from basidiomycetes in a forest soil," Soil Biology and Biochemistry, vol. 36, no. 7, pp. 1025-1036, 2004.

[17] M. L. Niku-Paavola, E. Karhunen, P. Salola, and V. Raunio, "Ligninolytic enzymes of the white-rot fungus Phlebia radiata," Biochemical Journal, vol. 254, no. 3, pp. 877-884, 1988.

[18] M. J. Han, H. T. Choi, and H. G. Song, "Purification and characterization of laccase from the white rot fungus Trametes versicolor," Journal of Microbiology, vol. 43, no. 6, pp. 555-560, 2005.

[19] H. Lowry, N. J. Rosebrough, A. L. Farr, and R. L. Randall, "Protein measurement with the folin phenol reagent," The Journal of Biological Chemistry, vol. 193, no. 1, pp. 265-275, 1951.

[20] A. Pandey, L. M. S. Palni, and D. Bisht, "Dominant fungi in the rhizosphere of established tea bushes and their interaction with the dominant bacteria under in situ conditions," Microbiological Research, vol. 156, no. 4, pp. 377-382, 2001.

[21] A. Ghildiyal and A. Pandey, "Isolation of cold tolerant antifungal strains of Trichoderma sp. from glacial sites of Indian Himalayan region," Research Journal of Microbiology, vol. 3, no. 8, pp. 559-564, 2008.

[22] A. Pandey, N. Das, B. Kumar, K. Rinu, and P. Trivedi, "Phosphate solubilization by Penicillium spp. isolated from soil samples of Indian Himalayan region," World Journal of Microbiology and Biotechnology, vol. 24, no. 1, pp. 97-102, 2008.

[23] K. Rinu and A. Pandey, “Temperature-dependent phosphate solubilization by cold- and $\mathrm{pH}$-tolerant species of Aspergillus isolated from Himalayan soil," Mycoscience, vol. 51, no. 4, pp. 263-271, 2010.

[24] K. Rinu and A. Pandey, "Slow and steady phosphate solubilization by a psychrotolerant strain of Paecilomyces hepiali (MTCC 9621)," World Journal of Microbiology and Biotechnology, vol. 27, no. 5, pp. 1055-1062, 2011.

[25] K. Rinu, A. Pandey, and L. M. S. Palni, "Utilization of psychrotolerant phosphate solubilizing fungi under low temperature conditions of the mountain ecosystem," in Microorganisms in Sustainable Agriculture and Biotechnology, T. Satyanarayana, B. N. Johri, and A. Prakash, Eds., pp. 77-90, Springer Science, Buisiness Media, 2012.

[26] J. Šnajdr and P. Baldrian, "Temperature affects the production, activity and stability of ligninolytic enzymes in Pleurotus ostreatus and Trametes versicolor," Folia Microbiologica, vol. 52, no. 5, pp. 498-502, 2007.

[27] M. A. Elsayed, M. M. Hassan, A. M. Elshafei, B. M. Haroun, and A. M. Othman, "Optimization of cultural and nutritional parameters for the production of laccase by Pleurotus ostreatus ARC280," British Biotechnology Journal, vol. 2, no. 3, pp. 115-132, 2012.

[28] G. Janusz, J. Rogalski, M. Barwińska, and J. Szczodrak, "Effects of culture conditions on production of extracellular laccase by Rhizoctonia praticola," Polish Journal of Microbiology, vol. 55, no. 4, pp. 309-319, 2006.

[29] A. Kocyigit, M. B. Pazarbasi, I. Yasa, G. Ozdemir, and I. Karaboz, "Production of laccase from Trametes trogii TEM H2: a newly isolated white-rot fungus by air sampling," Journal of Basic Microbiology, vol. 52, pp. 661-669, 2012.

[30] M. Manimozhi and V. Kaviyarasan, "Screening the effect of nutritional parameters on biomass and laccase production in submerged medium by litter decomposing basidiomycete Agaricus heterocystis," International Journal of Pharmacy and Pharmaceutical Sciences, vol. 4, no. 3, pp. 592-599, 2012.

[31] P. Keyser, T. K. Kirk, and J. G. Zeikus, "Ligninolytic enzyme system of Phanerochaete chrysosporium: synthesized in the absence of lignin in response to nitrogen starvation," Journal of Bacteriology, vol. 135, no. 3, pp. 790-797, 1978.

[32] J. A. Buswell, Y. Cai, and S. T. Chang, "Effect of nutrient nitrogen and manganese on manganese peroxidase and laccase production by Lentinula (Lentinus) edodes," FEMS Microbiology Letters, vol. 128, no. 1, pp. 81-87, 1995.

[33] E. Rosales, S. R. Couto, and M. A. Sanromán, "Increased laccase production by Trametes hirsuta grown on ground orange peelings," Enzyme and Microbial Technology, vol. 40, no. 5, pp. 1286-1290, 2007.

[34] I. Y. Lee, K. H. Jung, C. H. Lee, and Y. H. Park, "Enhanced production of laccase in Trametes vesicolor by the addition of ethanol," Biotechnology Letters, vol. 21, no. 11, pp. 965-968, 1999.

[35] A. Pandey, P. Trivedi, B. Kumar, B. Chaurasia, and L. M. S. Palni, Soil Microbial Diversity From the Himalaya: Need For Documentation and Conservation, vol. 5 of NBA Scientific Bulletin, National Biodiversity Authority, Tamil Nadu, India, 2006. 

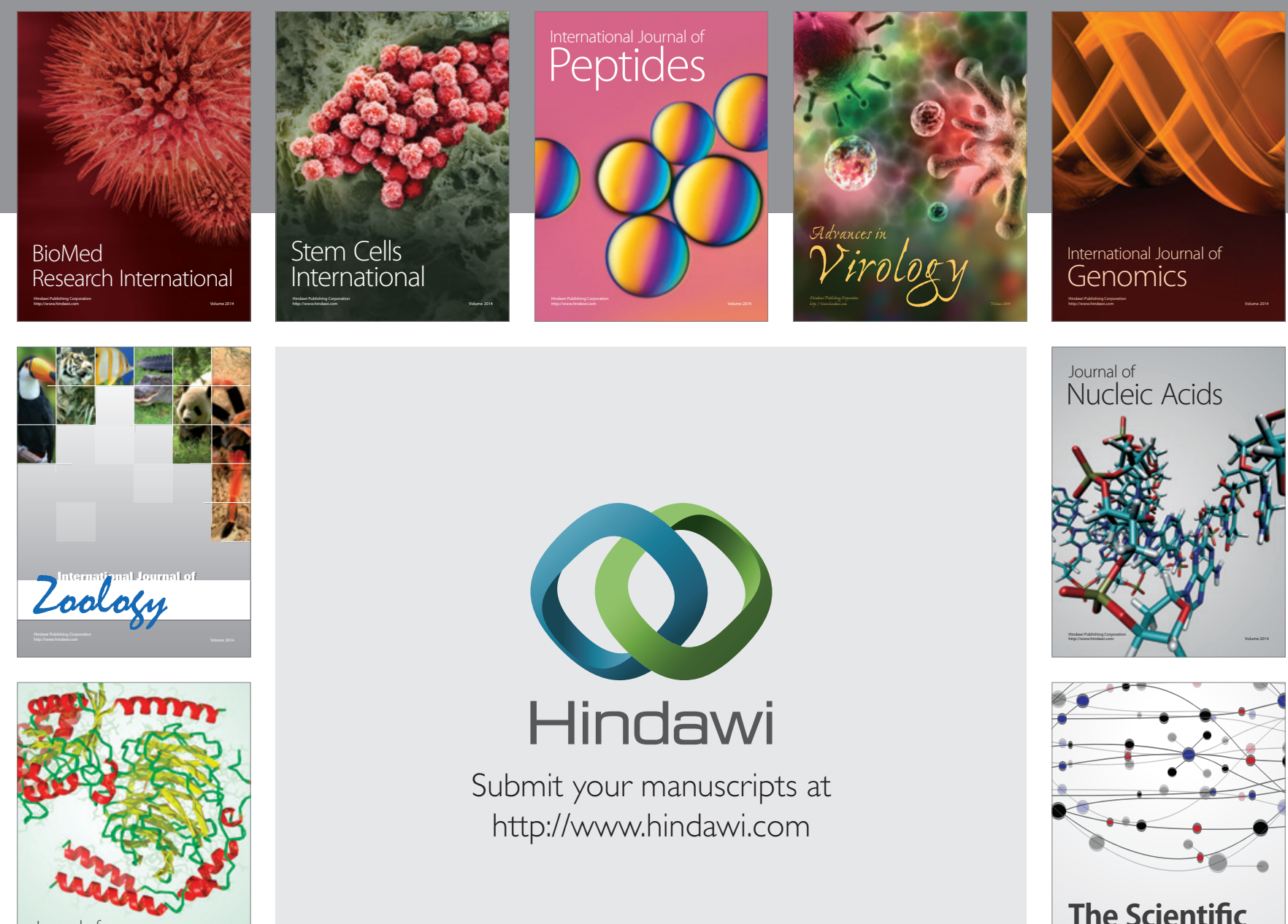

Submit your manuscripts at

http://www.hindawi.com

Journal of
Signal Transduction
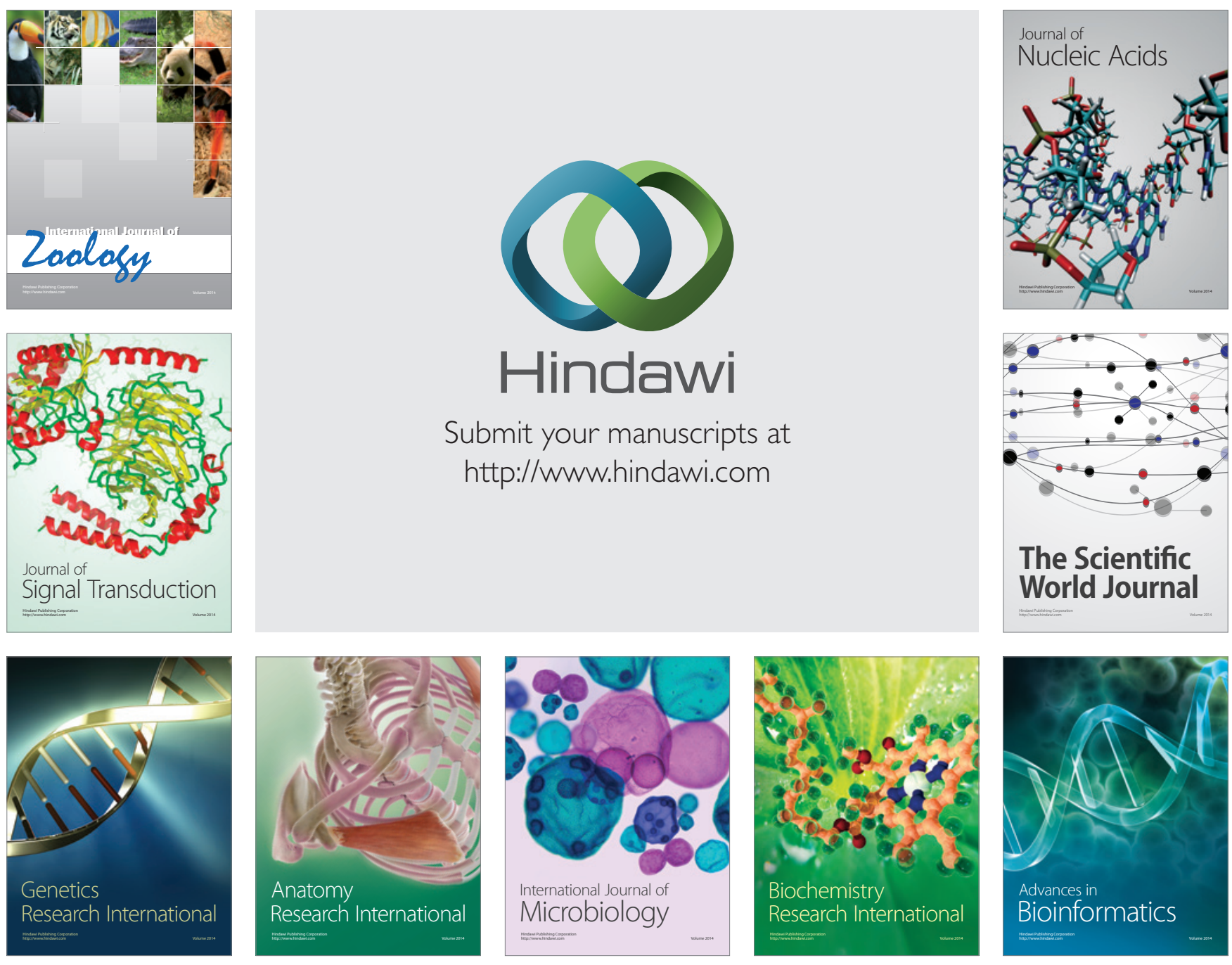

The Scientific World Journal
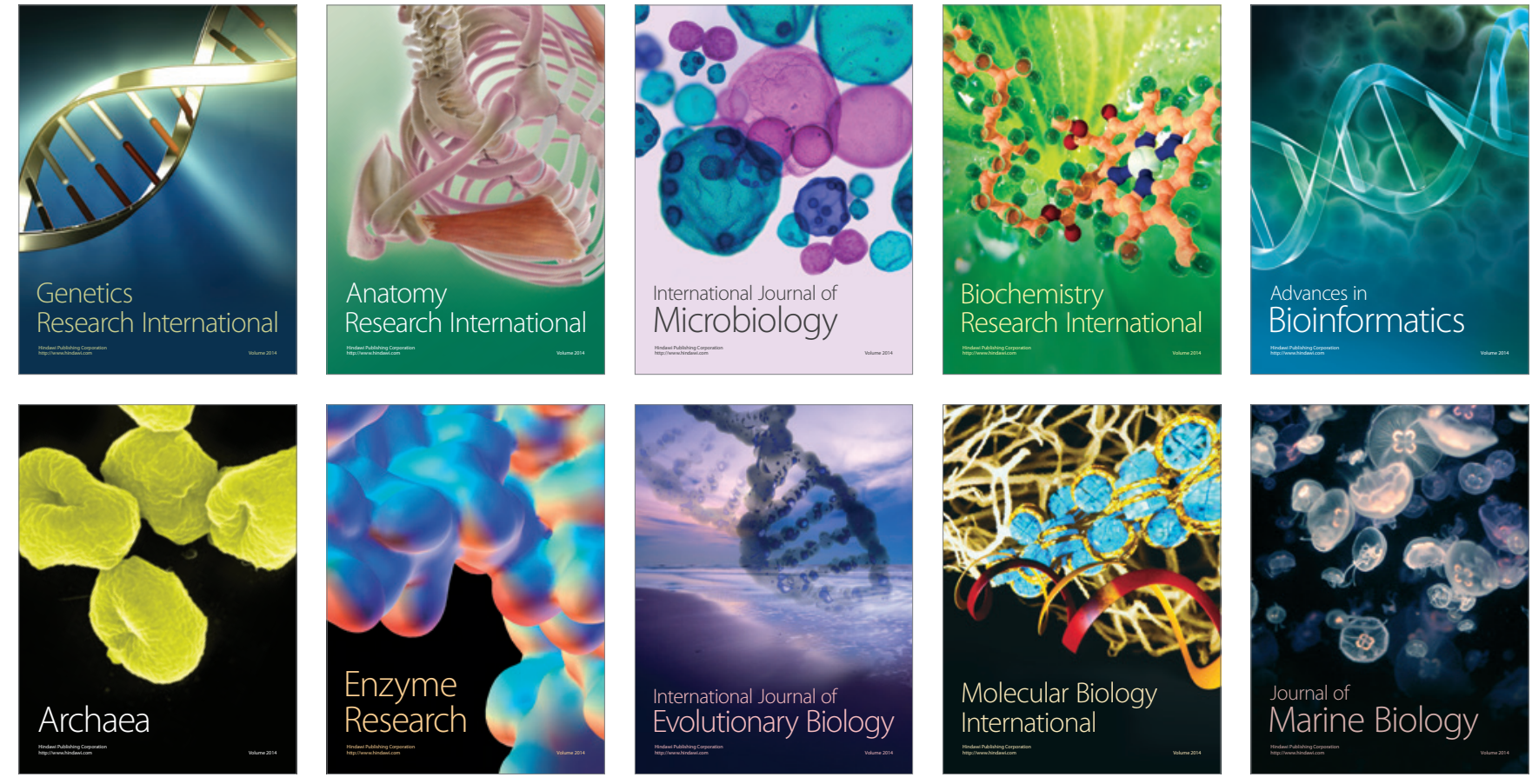